\title{
REMEDIES, REDRESS AND “CALLING TO ACCOUNT": SOME MYTHS ABOUT THE PARLIAMENTARY COMMISSIONER FOR ADMINISTRATION
}

\author{
Michael Buckley"
}

\section{INTRODUCTION}

One of the smaller institutional oddities of the United Kingdom is that while ombudsmen in the private sector officially bear that title, the same is not true of those in the public sector. The title of a public sector ombudsman is almost always some variation on "Commissioner" - whether or not there is a corresponding Commission. Northern Ireland is different in having the Parliamentary (or Assembly) Ombudsman for Northern Ireland (though that office too began life under the designation of "Northern Ireland Parliamentary Commissioner for Administration"). There is also the Prisons Ombudsman. However, just to add to the confusion of nomenclature, he is not accepted by the British and Irish Ombudsman Association as a true ombudsman, because he is appointed, and may be dismissed, by the Home Secretary, who is responsible for the Prison Service which he monitors; and he is therefore regarded by the Association as insufficiently independent to satisfy its criteria for full membership.

A much more substantial difference is that most ombudsmen whose jurisdiction includes the private sector make determinations or awards, and these are in many cases (though far from all) legally binding. Thus section 146 of the Pension Schemes Act 1993 says that the Pensions Ombudsman ${ }^{1}$ may investigate and determine any complaint or any dispute of fact or law arising in relation to an occupational or personal pension scheme; and section 151(3) provides that the determination is final and binding on both the complainant and the trustees or managers of the pension scheme, subject to appeal to the High Court or Court of

- The Parliamentary Commissioner for Administration.

1 More exactly, the "commissioner to be known as the Pensions Ombudsman" (section 145(1)): the draftsman apparently could not quite bring himself to abandon the hallowed word. 
Session on a point of law. By contrast, ombudsmen whose jurisdiction is confined to the public sector have in general no power to make binding awards. ${ }^{2}$

This is in accordance with the normal international pattern. Dr Marten Oosting, the National Ombudsman of the Netherlands and President of the International Ombudsman Institute, says:
"Almost universally, the ombudsman does not have the power to take legally binding decisions."

In the same article, Oosting goes on to say:

\begin{abstract}
"Generally speaking, therefore, the ombudsman cannot formally compel the authorities to take the action he recommends. It is therefore of paramount importance that the institution of the ombudsman, and the person holding that office, generate so much respect and authority that they nevertheless can count on their conclusions being accepted by the authorities to whom they are addressed. This is ... one of the essential elements of ombudsmanship."
\end{abstract}

The purpose of this paper is to suggest that the Parliamentary Commissioner for Administration [P.C.A.] as originally conceived was expected, indeed intended, to lack that "essential element," which would be supplied by proceedings in Parliament; and to explore some of the ways in which this fact has influenced the development of the ombudsman institution in the public sector in Great Britain.

\title{
A PARLIAMENTARY COMMISSIONER, NOT AN OMBUDSMAN
}

It is well known that those who devised the institution of the P.C.A. did not wish to appear to be supplanting the Member of Parliament in his or her traditional role of securing redress of grievances on behalf of the citizen. The White Paper published in 1965, said:

${ }^{2}$ Again, Northern Ireland is an exception: awards by the Northern Ireland Commissioner for Complaints may be enforced through the courts.

3 "Essential Elements of Ombudsmanship" in The Ombudman Concept Linda C. Reif, (ed.) (1995, International Ombudsman Institute). 


\section{REMEDIES, REDRESS \& "CALLING TO ACCOUNT"}

"In Britain, Parliament is the place for ventilating the grievances of the citizen...It is one of the functions of the elected Member of Parliament to try to secure that his constituents do not suffer injustice at the hands of the Government... Members are continually taking up constituents' complaints in correspondence with Ministers, and bringing citizens' grievances, great or small, to Parliament, where Ministers individually and Her Majesty's Government collectively are accountable. We do not want to create any new institution which would erode the functions of Members of Parliament in this respect, nor to replace remedies which the British Constitution already provides. Our proposal is to develop those remedies still further. We shall give Members of Parliament a better instrument which they can use to protect the citizen, namely, the services of a Parliamentary Commissioner for Administration."

During the passage of the Parliamentary Commissioner Act 1967, Ministers consistently denied that what they were creating was an ombudsman on Scandinavian lines. The following extracts from the speech of Mr. Richard Crossman during Second Reading are typical:

"In asking the House to give the Bill a Second Reading, I want to start by repudiating a notion which has got about, that in this Bill we are borrowing from other countries and trying to force into our British constitutional mould the notion of the Ombudsman which has been the pride of Sweden for 150 years."

"[W]e have decided unequivocally that the Parliamentary

Commissioner must remain permanently a servant of the House."

Crossman's speech placed much emphasis on the new Commissioner as "an extremely sharp and piercing instrument of investigation" in the hands of the backbench Member. He would establish the facts and report them to the

${ }^{4}$ The Parliamentary Commissioner for Administration (Cmnd.2767, H.M.S.O., 1965) at para. 4 .

${ }^{5} 734$ H.C. Deb.col.51 (18th.October, 1966).

${ }^{6}$ Ibid. col. 49. 


\section{THE DENNING LAW JOURNAL}

Member. ${ }^{7}$ The Notes on Clauses took the same line.

"The institution proposed for this country [the P.C.A.]...has been designed as an instrument in the hands of Members of Parliament for establishing with greater penetration the facts about administrative actions and their results." ${ }^{18}$

So the Commissioner would establish the facts. But then what? The 1967 Act contains much about investigations and reports; but its only reference to remedies or redress is in section 10(3), which empowers the Commissioner, if he considers that an injustice consequent on maladminstration has not been, or will not be, remedied to lay a special report on the case before each House of Parliament.

\section{REMEDIES}

The thinking on the matter of remedies of those who created the 1967 Act seems to have shifted during its passage. If it was essential that the new Commissioner should not encroach on the historic right and duty of Parliament, and the constituency Member in particular, to secure redress of grievances, it was logical to confine his powers to investigating and reporting and to minimise his role in securing redress. The Labour Party Manifesto for the 1964 General Election did not even mention such a role. It proposed only to set up a "new office of Parliamentary Commissioner with the right to investigate the grievance of the citizen and report to a select committee of the House."

The White Paper went rather further, but still assigned a largely passive role in the matter to the Commissioner:

"If he finds that there is justifiable cause for complaint and the Department responds to his invitation to put it right, he will inform the Member... If the Department does not act to the Commissioner's satisfaction, it will be open to him to report his conclusions to

7 Ibid. col. 60. Privately, as his Diaries show, Crossman was sceptical, even contemptuous, of the effectiveness of the powers contained in the Parliamentary Commissioner Bill, apart from the powers of investigation. See the entries for 18th.October, 1966 and 24th.January, 1967.

${ }^{8}$ Notes on Clauses, vii.II, p.3. 


\section{REMEDIES, REDRESS \& "CALLING TO ACCOUNT"}

Parliament ad hoc."

If anything, the Notes on Clauses are a retreat from the White Paper. They criticise the rival proposal ${ }^{10}$ of the Conservative Party for an Administration Commission on the grounds that:

"it attempts to take the task of investigating and correcting administration away from the sphere of responsibility of Parliament and Ministers. Members might act as a channel to the Administration Commission, but after that they would have, apparently, no further part to play in the matter."

"... in the Government's plan .. while the Commissioner may only investigate administration, responsibility for any action beyond investigation is left with Parliament and with Ministers."

"the Commissioner's function will be purely to investigate and to report to Parliament. The further processes will be for Parliament...In practice the process might well be pressure in suitable cases from Parliament on a Department to improve the redress offered by them, and even to make some compensatory payment; and the department might find it necessary to satisfy Parliament that the amount of any proposed payment was sufficient."

Essentially, then, redress was seen as a matter for Parliament, not the Commissioner; and the Commissioner's main weapon would be a threat of Parliamentary action.

${ }^{9}$ Supra. n.4 at para. 11

${ }^{10}$ In a pamphlet entitled Let Right be Done, prepared by the Inns of Court Conservative and Unionist Society, and published in January, 1966.

11 Notes on Clauses, vol.I, para. 117.

${ }^{12} \mathrm{Ibid}$. The discussion is directed to the distinction (or lack of it) between policy and administration; but the comment is still revealing.

${ }^{13}$ Ibid. para. 122 
"By making [a report under what became section 10(3) of the 1967 Act] or threatening to do so, the Commissioner may, through Parliament, exert pressure on a department to alter the action that it has taken...The subsequent action will not be for the Commissioner; it will be for Parliament, using whatever machinery - for example, a Select Committee of the House of Commons - is devised by Parliament for the purpose."14

However, during the later stages of the passage of the Bill through the Commons Ministers were assigning a significantly more active role to the Commissioner. On 15th. November, 1966, during Committee Stage, Mr. Roots moved an amendment empowering the P.C.A. to state in any report "what remedy he considers appropriate to right the injustice to the complainant, including the payment of compensation."

One member of the Committee, Mr. Coe, objected to this: the P.C.A. should be "the person who finds out"and not be given "what would in effect be virtually executive powers."

He added:

"Once one started saying 'This is how this case should be satisfied' would not this make the Commissioner's whole position difficult?"16

On the face of things, that was fully in accordance with the impression of the Commissioner's powers which the Government had fostered. However, Mr. MacDermot (then Financial Secretary to the Treasury, and responsible for piloting the Bill through Committee) said that the amendment was unnecessary "[w]e do not feel that this adds anything of substance to the Bill."17 (Even then, he did not go very far:

"we do not want, and do not intend, that the Commissioner himself

${ }^{14}$ Notes on Clauses, vol.II, p.64.

${ }^{15}$ Standing Committee Debates, Standing Committee B, Official Report, col. 302.

${ }^{16}$ Ibid. col.303.

${ }^{17}$ Ibid.col. 304 . 


\section{REMEDIES, REDRESS \& "CALLING TO ACCOUNT"}

should be called on to assess the compensation, the quantum of the amount to be paid."18

although he might "if we take an extreme case" say if he thought the proposed compensation was far too small, so that the injustice had not been remedied.

"[I]t would change the whole character of the Commissioner if we were to set him up as a tribunal to assess compensation; and neither do we want to confer on him the burden of deciding what shall be done in detail.")

In advancing this argument, Mr. MacDermot chiefly relied on the provisions of clause 10(2) (now section 10(3)) of the Bill.

"[T] here is nothing in the Bill to prevent [the P.C.A.'s indicating in his report the remedy he thinks is called for] and, by implication, he is expected to do it when he thinks it is proper. This is the weight which I am attaching to the provision in [section 10(3)] because that shows that he must direct his mind to the adequacy of the remedy which either has been decided or is proposed. Since he has to direct his mind to it, it is obviously proper that he should be able to comment upon it in his report. Indeed, we have gone further than that in laying the duty upon him, if he thinks that the remedy is inadequate, to make a special report." 19

However, one is bound to wonder whether the clause was really appropriate to this revised attitude. It was one of the original provisions of the Bill, and reflected the initial intention of those who prepared it, that redress was a matter for Parliament. Mr.MacDermot, an accurate lawyer, cannot really have directed his mind to the clause, since he was plainly mistaken in suggesting that the subsection imposes a duty on the Commissioner to report. ${ }^{20}$ The text did not

${ }^{18} \mathrm{Ibid}$. col.305.

${ }^{19}$ Ibid. col.308.

${ }^{20}$ With whatever justification, or lack of it, Crossman believed that MacDermot had been disingenuously furthering what Crossman saw as the Treasury's aim of stripping the Commissioner of any effective power. See the Diary entries for 24th.January, and 15th.February, 
change during the passage of the Bill. It states that the Commissioner may lay a special report before Parliament if he sees fit [emphasis added]. Obviously it confers a power, not a duty. (However, in fairness, even if the route was wrong, the result was probably right, since the existence of a power carries the duty to consider using it.)

\section{THE SELECT COMMITTEE}

It is not clear what led to the change of emphasis; but it seems likely that a significant cause was a growing realisation that unless the Parliamentary Commissioner had considerably stronger powers, de facto if not de jure, an impossible burden would be laid upon Parliament. (The process of adjustment to reality was perhaps accelerated by the appointment after Second Reading of the Bill in the Commons of Sir Edmund Compton, then Comptroller and Auditor General, as P.C.A. designate.) The original conception had been that if the Member who referred the complaint to the Commissioner could not secure redress for the complainant it would become a matter for the House of Commons as a whole, acting through a Select Committee. The Government was scrupulous in not appearing to wish to prejudge a decision that was for the House of Commons alone to take; but the passages cited above ${ }^{21}$ give a clear enough indication of its thinking, as does this one from the White Paper:
"It will be for Parliament to decide what arrangements to make to receive and act upon reports from the Commissioner...It may well be found convenient to establish a Select Committee to take these reports in the first instance. This Committee would have the usual powers of a Select Committee to summon witnesses (including Ministers) and to take evidence and report to Parliament."22

Indeed, the Labour Party's original proposals in their Manifesto, and a speech by Mr. Harold Wilson at Stowmarket on 3rd. July, 1964, had emphasised the roles of the new Commissioner and the Select Committee and made little of the role of the individual Member. Comparisons were drawn between the P.C.A. and

1967.

${ }^{21}$ Supra. n.11-14 \& text.

${ }^{22}$ Supra. n.4 at para. 12 . 


\section{REMEDIES, REDRESS \& "CALLING TO ACCOUNT"}

his Select Committee on the one hand and the Comptroller and Auditor General and the Public Accounts Committee on the other. In his speech, Mr. Wilson (who had been Chairman of the Public Accounts Committee from 1959 to 1963) likened the Commissioner to the Comptroller and Auditor General:

"Just as the reports of the Comptroller and Auditor General and the Public Accounts Committee are capable both of highlighting individual cases of waste, and of commenting on weaknesses in the system of expenditure control, so the proposed new Commissioner and the related select committee would have the same opportunities to highlight individual cases of injustice as well as general defects in the system."23

The Notes on Clauses took a similar line:

"The institution proposed for this country...has been designed as an instrument in the hands of Members of Parliament for establishing with greater penetration the facts about administrative actions and their results when someone claims to have suffered injustice thereby. This design owes every bit as much to our own office of Comptroller and Auditor General and to British Parliamentary practice as to other countries offices of Ombudsmen."

Similarly, Mr.Crossman had talked of "a Parliamentary Commissioner modelled on the Comptroller and Auditor General,"25 and Mr. MacDermot had said:

"Our proposals...are based on long experience... of the officer of Parliament, the Comptroller and Auditor General. The precedent of that office has been followed very closely in framing these proposals." 26

${ }^{23}$ Quoted in Notes on Clauses, vol.I, para. 103.

${ }^{24}$ Ibid., vol.II, p.3.

${ }^{25} 734$ H.C. Deb. col.46 (18th.October, 1966).

${ }^{26}$ Ibid. col 164. 
A moment's reflection would have shown that these analogies were seriously misleading. Neither the Comptroller and Auditor General nor the Public Accounts Committee look at the grievances of individual citizens; their investigations are in no way dependent on the making of complaints by individual citizens, or on referrals of cases by individual Members; they have no function of considering redress for individual grievances; and the number of cases examined in a year by the Public Accounts Committee is small. Contrariwise, the P.C.A. cannot investigate administrative systems, as Mr. Wilson had suggested, except as part of the investigation of an individual complaint: he cannot draw up, as the Comptroller and Auditor General can, a programme of systems' audit.

One of the most striking things to the eye of a modem reader is the complete absence in the debates on the Parliamentary Commissioner Bill of any estimate of workload. However, it is unlikely to have been lower than the number of complaints actually received from Members: 816 in the first nine months of $1967^{27}$ and 1,120 in $1968 .{ }^{28}$ Indeed, in a press interview in April, $1967 \mathrm{Sir}$ Edmund Compton said that he expected to receive 6,000 to 7,000 complaints a year. ${ }^{29}$ If only five per cent of the actual number of cases received were eventually considered by the Select Committee, the Committee would have had to hold hearings on 50 or more cases a year; and this, let alone the far higher number implied by Sir Edmund Compton's figure, would have been quite impracticable.

It is therefore not surprising that statements by Government spokesmen progressively envisaged a larger role for the Commissioner and a smaller one for the Select Committee. Thus by Report Stage Mr. MacDermot was ready to go further than before in implying that the P.C.A. would discuss redress with departments:

"[T]here would be the special report procedure under [section 10(3)] by which when the Commissioner considered that there was an unresolved injustice, that he had reached deadlock with the Department and that the Department was not taking sufficient action ... he would report to Parliament and that report would be

${ }^{27} 1967$ Annual Report, H.C. $134(1967-68)$ at p.4.

${ }^{28} 1968$ Annual Report, H.C. $138(1969-70)$ at p.3.

${ }^{29}$ Frank Stacey, Ombudsmen Compared, (Clarendon, 1978) at p. 129. 


\section{REMEDIES, REDRESS \& "CALLING TO ACCOUNT"}

considered by the Select Committee. ${ }^{" 30}$

And by Second Reading in the House of Lords, Lord Gardiner, the Lord Chancellor, was saying:

"Although the Commissioner has no power to make orders, it is thought that it will be very rare in practice that a Minister will not do what the Commissioner advises and that the Commissioner will have to report to the House of Commons, where a Select Committee will be appointed...The only function of the Select Committee will be to deal with any Minister who does not comply with the recommendations of the Commissioner."31

Nevertheless, the earlier concept of the role of the Select Committee had, and continues to have, a significant effect on perceptions of the functions of the P.C.A., and on the way in which the system of public sector ombudsmen has developed in the United Kingdom. The rest of this paper briefly examines two aspects of this: the fragmentation of jurisdiction in the British system of public sector ombudsmen; and what is said about the status and method of working of the P.C.A. in the Government's proposals for an Information Commissioner.

\section{FRAGMENTATION}

The typical pattern internationally is that if there is a national ombudsman, he or she will have within jurisdiction a wide range of public services, including central government, local authorities, the public health service, schools, and the police. ${ }^{32}$ Examples are to be found in Denmark, France, and the Netherlands, though there are, of course, differences of detail. Here in Britain alone there are the Parliamentary Commissioner for Administration (central government), the Health Service Commissioner (N.H.S.), the Commission for Local Administration (local government), and the Police Complaints Authority (police).

Early discussion of the possibility of establishing an ombudsman in the United Kingdom had envisaged a pattern similar to that in other countries. An influential

${ }^{30} 739$ H.C. Deb. col. 1402 (24th.January, 1967) [emphasis added].

${ }^{31} 279$ H.L. Deb. col.1378 (8th.February, 1967).

32 The situation is naturally different in countries with a federal constitution. 
work, Occasion for Ombudsman by T.E.Utley published in 1961, contained a number of studies of cases involving alleged abuses by various public sector bodies, and in which it was suggested that an ombudsman would have a valuable part to play. Of the dozen or so cases quoted not a single one is within the jurisdiction of the P.C.A.; and fewer than half would be within the jurisdiction of any ombudsman even today.

The 1965 White Paper had also envisaged the possibility in this country of an arrangement much closer to what has become the international norm:

"In due course, it may be desirable to consider extending the powers
of the Commissioner to deal with complaints of the private citizen
against the administrative actions of other public authorities. But,
first, we intend to seek experience of the Commissioner in the field
of relationships between the citizen and central Government."33

However, such an extension was manifestly impossible if the Commissioner was to be no more than an instrument in the hands of Members seeking to remedy grievances against bodies directly accountable to Parliament, and those who refused to provide adequate redress were to be brought into line by being called to appear before a Select Committee of the House of Commons. Mr. MacDermot made the point very clear on Second Reading:

"The Commissioner will be reporting to a Committee of this House.
This House ${ }^{34}$ will then have power to investigate, to call for persons
and papers, and to summon officials. To consider summoning
councillors about the way in which they are administering their local
affairs would be out of the question."35

Mr. Crossman took the same line: he expressed the view that it should be left:

"to elected local authorities to work out their own way of equipping their councillors with an office designed to remedy individual

${ }^{33}$ Supra.n. 4 at para. 17.

${ }^{34}$ This may have been a slip of the tongue for "Committee."

${ }^{35}$ Supra.n.25 at col.169. 


\section{REMEDIES, REDRESS \& "CALLING TO ACCOUNT"}

grievances of ratepayers by means of a searching investigation." 36

Similar arguments are current even today. For example, paragraphs 6 to 23 of the Report of Stage II of the Financial Management and Policy Review of the Commission for Local Administration (C.L.A.) in England, published in August 1996, contains a long discussion of the suggestion of the English C.L.A. that the terms of reference of the Select Committee on the P.C.A. (now the Select Committee on Public Administration) should be enlarged to include the C.L.A.. Similar proposals have been put forward in the past; and Annex B to the Report contains a convenient short history of their consideration.

It is impossible to do full justice to the discussion in the Report in the confines of this paper. However, I do not think it is seriously misleading to say that it shows that historically the main argument in favour of extending the Select Committee's terms of reference in the way under consideration has been a belief that this would increase the probability that the recommendations of the Local Government Ombudsmen would be given effect; and the main argument against has been a belief that it would be inconsistent with the constitutional position of local authorities. The following extracts from the Report make these points:

"The decision on whether to extend the orders of reference of the Select Committee on the P.C.A. would be for the House of Commons as a whole, voting on amendments to standing orders which would normally be presented by the Leader of the House. The issue is one which the Committee itself has considered more than once... On their first look at the subject they accepted that it would be inappropriate for a select committee of the House of Commons to call democratically elected local authorities to account.

Later they saw advantage in extending their jurisdiction in order to summon recalcitrant councils to explain themselves. The debate has therefore been focused on whether an extension of jurisdiction would help to ensure that the Local Government Ombudsmen's recommendations are accepted."37

"Balanced against all these considerations is a fundamental

${ }^{36}$ Ibjd.col. 57 .

${ }^{37}$ Report of Stage II of the Financial Management \& Policy Review of the Commission for Local Administration, para. 10. 


\section{THE DENNING LAW JOURNAL}

constitutional point that has from time to time been considered an overriding objection to extending the select committee's remit: that arrangements in which local authorities were required to answer to a Select Committee of Parliament for their administrative systems and responses to reports from the Local Commissioners would be constitutionally inappropriate, undermining the responsibility of independent local authorities to their own local electorates. ${ }^{.38}$

\section{THE FREEDOM OF INFORMATION WHITE PAPER}

Paragraph 5.7 of the White Paper, Your Right to Know discusses the status and method of working of the proposed Information Commissioner by reference to those of the P.C.A. ${ }^{39}$ It may well contain more mistakes of fact and law than any other single paragraph in an official public document. To mention only those relevant to the discussion in this paper, it implies that the P.C.A. is accountable to Parliament for his conduct of, and conclusions on, individual investigations; that his recommendations depend for their acceptance on political processes; and that public bodies not accountable to Parliament in the same way as Government departments and agencies, because they could not be "called to account" by the Select Committee, could not be subject to the jurisdiction of an Information Commissioner operating in the same way as the P.C.A.

It is elementary law, and was recognised from the outset, that the 1967 Act established the P.C.A. as an independent office holder, whose methods of investigation and findings in individual cases were matters solely for his discretion, subject to the provisions of the Act. Again, as will be argued later in this paper, the role of the Select Committee in examining the P.C.A.'s findings and "calling to account" is very different from that assumed by the White Paper. Yet another of the White Paper's implications - that the P.C.A.'s findings or recommendations are subject to some form of political override - is equally without foundation. Curiously enough, it echoes a criticism of the 1965 proposals voiced by the Conservative Party at the time: that the party system would prevent Parliament from providing effective and speedy redress when the Commissioner reported adversely. ("Redress" meant reversal of the criticised action, or

\footnotetext{
${ }^{38}$ Ibid. at para. 9.

${ }^{39} \mathrm{Cm} .3818$, The Stationery Office, 1997 at para.5.7.
} 
compensation if this was impossible. $)^{40}$

\section{"CALLING TO ACCOUNT"}

The phrase "calling to account" is used in a variety of senses. In its stronger senses it carries the connotation of being able to impose disciplinary sanctions, up to and including dismissal. Not far removed is the idea of requiring the body or person "called to account" to take certain action on pain of such sanctions. It seems clear that the discussion reflected in the earlier part of this paper uses the phrase in one of those stronger senses; and the following paragraphs do likewise. That is not to say that other senses are not important and relevant, only that their implications for, in particular, the constitutional issues touched on in this paper are significantly different.

In my view, much of the discussion summarised in the previous three headings is based on misconceptions dating back to the preparation and passage of the 1967 Act and the misleading analogies between the P.C.A. and Select Committee on the one hand and the Comptroller and Auditor General and the Public Accounts Committee on the other, which are discussed above. ${ }^{41}$ As Professor Roy Gregory has pointed out, errors in this field can be very hard to root out. ${ }^{42}$ These particular ones have little or no foundation, either in constitutional theory or in the way in which the Select Committee has actually operated in its 30 years' existence.

First, it is not the Committee's normal practice to examine reports by the P.C.A. on individual investigations, ${ }^{43}$ though it does refer to such reports in its questioning of Permanent Secretaries or agency Chief Executives if they or the general issues which they illustrate have been highlighted in the P.C.A.'s Annual. Report or one of his regular volumes of Selected Investigations.

Secondly, it is not the Committee's practice to involve itself in securing redress for individual complainants, and only seldom has it involved itself in redress for

${ }^{40}$ See Notes on Clauses, vol.I, p.65.

${ }^{41}$ See n. 23-26 \& surrounding text.

${ }^{42}$ See "The Ombudsman Observed" in The International Ombudsman Yearbook vol.1, p.87.

${ }^{43}$ Technically, reports to individual Members under section 10(1) of the 1967 Act. 


\section{THE DENNING LAW JOURNAL}

groups or classes of complainant. Even in the famous Sachsenhausen case, ${ }^{44}$ often regarded as the case which established the effectiveness of the P.C.A. as an institution, the Government accepted the P.C.A.'s findings (and in fact went beyond them) before the Select Committee had considered the P.C.A.'s report: the Committee was much put out by this. ${ }^{45}$ Moreover, the Government, by its own account, did this not because it agreed with the P.C.A.'s findings or, self-evidently, because of pressure from the Committee, but "out of respect for the Commissioner's judgement and to support the authority of his office."

Thirdly, despite this lack of involvement in individual cases on the part of the Committee, the P.C.A.'s recommendations have very seldom been rejected by departments or agencies. Contrary to the heavy emphasis put on it by much of the discussion at the time of the $1967 \mathrm{Bill},{ }^{47}$ there has been very little use of the power to make special reports under section 10(3) of the Act. There have been only two such reports; and both - that on the refusal to meet late claims for compensation after the upgrading of the Rochester Way, Bexley ${ }^{48}$ and that on the Channel Tunnel Rail Link ${ }^{49}$ - as well as finding that there was maladministration, have raised issues of policy and public expenditure which one might well argue were for Parliament alone to settle.

Fourthly, and by contrast, the Committee does regularly take evidence from the relevant N.H.S. body on reports from the Health Service Commissioner (H.S.C.) on individual cases. This has been justified on the grounds that it is appropriate for the Committee to call to account "public bodies such as health authorities, which provide a service for which the Secretary of State is ultimately accountable and which are subject to his direction." 50 Whatever the merits of that argument in

${ }^{44}$ The P.C.A. reported the case under section 10(4) of the Act on 20th. December, 1967, [H.C. 54 (1967-68)]; it was debated in the House of Commons on 5th.February, 1968; and the Select Committee reported on it on 16th.May, 1968 [H.C. 258, (1967-68)].

45 "Your Committee think it was unfortunate that the debate in Parliament preceded the examination of the case by the Select Committee." [ibid.at para.1].

${ }^{46} 758$ H.C. Deb.col. 115-117 (5th.February, 1968).

${ }^{47}$ See n. $10-14 \&$ text; n. $19 \& 20$ \& text; n. 30 \& 31 \& text.

${ }^{48}$ H.C. $598(1977-78)$.

${ }^{49}$ H.C. $193(1994-95)$.

${ }^{50}$ Select Committee on the P.C.A., Second Report 1979-80, (H.C. 254) at para. 20. 


\title{
REMEDIES, REDRESS \& "CALLING TO ACCOUNT"
}

the past, its force has been greatly weakened by the passage of the National Health Service and Community Care Act 1990. Section 5 of that Act establishes N.H.S. trusts as independent bodies corporate; and the ability of the Secretary of State to give them directions is constrained by the provisions of the Act. Paragraph 18 of Schedule 2 makes the position clear:

\begin{abstract}
"An N.H.S. trust shall not be regarded as the servant or agent of the Crown or, except as provided by this Act, as enjoying any status, immunity or privilege of the Crown; and an N.H.S. trust's property shall not be regarded as property of, or property held on behalf of, the Crown."
\end{abstract}

Although the Secretary of State has power to dismiss the Chairman and other non-executive directors of a trust and so "call them to account," he has no power to dismiss or discipline the executive directors (who are responsible for day-to-day management) since they are employees of the trust ${ }^{51}$ and accountable to it alone. It therefore seems clear that when the Select Committee takes evidence from, say, the Chief Executive of an N.H.S. Trust it cannot be said to be calling him or her to account in the sense of the phrase relevant to this discussion.

The point will become still clearer if, as seems inevitable, the Select Committee takes evidence from general medical or dental practitioners when it considers reports by the H.S.C. following the extension of his jurisdiction under the Health Service Commissioners (Amendment) Act 1996 to include the family health services: such practitioners are independent contractors, not public employees, and are not legally accountable, except as their conditions of service provide, to N.H.S. purchasers, let alone the Secretary of State, or Parliament.

There is no doubt that the adverse publicity which invariably follows on a critical hearing before the Select Committee, or criticism in one of its reports, has a powerful persuasive effect on N.H.S. bodies to accept and act on the H.S.C.'s recommendations without lengthy debate. The prospect of a critical hearing before the Committee also profoundly affects the attitude of those who work in the N.H.S. to the investigations and recommendations of the H.S.C.. But there is no reason to suppose that those recommendations would not eventually be accepted in the great majority of cases, just as those of the Local Government Ombudsmen are.

${ }^{51} \mathrm{~S} .5(5)(\mathrm{a})$ 


\section{THE "M.P. FILTER"}

Finally, it is worth saying a few words about the "M.P. filter" - the provision in section 5(1) of the 1967 Act that the P.C.A. may investigate only complaints referred to him by a member of the House of Commons. This provision applies to virtually no other ombudsman in the world: the only exceptions known to me are France and, I believe, Sri Lanka. It was logical enough under the original conception of the P.C.A. Since it was assumed that his role was to help Members secure redress for justified grievances, not to secure redress for them himself, there could be no point in providing direct access to him. The reality, as this paper has tried to show, is entirely different from the assumption; and the main effect of the "M.P. filter," so far as the citizen with a complaint against the Government is concerned, is to deprive him or her of choice in the method of pursuing it.

\section{CONCLUSION}

I suggest that the discussion in this paper leads to the following conclusions.

First, practice in this country is in reality very close to the international norm as described by Dr. Oosting.: ${ }^{22}$ the recommendations of the P.C.A., and those of other public sector ombudsmen, are accepted out of respect for them and their authority, and not because of actual or threatened proceedings in Parliament.

Secondly, the Select Committee has seldom involved itself in matters of redress; and when it has involved itself, it has been concerned with general policy, or the treatment of a significant class of complainants, often carrying the possibility of substantial public expenditure.

Thirdly, in this respect and others it is far more fruitful to regard the activities of the Select Committee as directed mainly towards issues of policy or management than as enforcing the acceptance of recommendations or "calling to account" (in the sense used in this paper), which are relatively minor aspects.

The position is well described in the following extracts from reports by the present Committee's predecessors:

"Following our past practice, we decided to enquire into a number of categories of complaint discussed in the Commissioner's Annual Report, in the hope that lessons of general application might be

${ }^{52}$ See n. $3 \&$ text. 


\section{REMEDIES, REDRESS \& "CALLING TO ACCOUNT"}

drawn from them...We selected...cases which illustrated the kind of problems which arise and took evidence on these from the health authorities concerned as well as from the health departments." 53

"The chief advantage of extending our jurisdiction (sc to cover local authorities) would be that it would not create a direct method of enforcement to be imposed on authorities...Instead, the force of persuasion...would be enhanced by the prospect of recalcitrant authorities being summoned to explain themselves before us. This method is all the enforcement needed by the Parliamentary Commissioner for Administration in mainland Britain and, as we know from our own experience, it provides an effective method of support for him in the exercise of his functions." 54

"We therefore considered various methods of ensuring that reports from local ombudsmen are implemented along the lines of those of the Parliamentary Commissioner for Administration: that is, that authorities may discuss points of disagreement, which is quite fair and proper, but in the end must respect the judgement of those appointed to investigate complaints against them. ${ }^{255}$

Indeed, the argument has come full circle. The reality is that the Select Committee is doing something very similar to what the Public Accounts Committee actually does rather than what those who prepared and piloted the 1967 Act represented it as doing: that is, the Select Committee takes evidence from whomever it wishes, partly to call to account those who are already directly accountable to Parliament, but much more to assemble evidence as a basis for formulating recommendations to Government. It could, without difficulty, continue to do this whatever the structure of the system of public ombudsmen in this country, and whatever the form of accountability of those bodies which are investigated by the ombudsmen. The pity is that the misconceptions of 1966 and 1967 have had more influence than the reality on the formulation of important aspects of subsequent policy.

\footnotetext{
${ }^{53}$ H.C. $621(1980-81)$ at para. 9.

${ }^{34}$ H.C. $448(1985-86)$ at para. 29.

${ }^{5 s}$ Ibid.at para. 18.
} 